\title{
Pebula: Local wisdom of the Buton people considering the prevention and enforcement of corruption
}

\section{Pebula: Kearifan lokal masyarakat buton dalam pencegahan dan penindakan korupsi}

\author{
La Ode Abdul Munafi ${ }^{1}$, Tasrifin Tahara ${ }^{2}$, Andi Tenri³ ${ }^{3}$ Dinna Dayana La Ode Malim \\ ${ }_{1}^{1}$ Department Sociology, Dayanu Ikhsanuddin University, Indoneseia. E-mail: Imunafi@yahoo.com \\ 2 Department of Anthropology, Hasanuddin University, Indoneseia. E-mail: tasrifin.tahara@yahoo.co.id \\ ${ }^{3}$ Department Sociology, Dayanu Ikhsanuddin University, Indoneseia. E-mail: anditenri@unidayan.ac.id \\ ${ }^{4}$ Faculty of Law, Dayanu Ikhsanuddin University, Indoneseia. E-mail: dinnadayana@gmail.com
}

\begin{tabular}{|c|c|}
\hline ARTICLE INFO & ABSTRACT \\
\hline $\begin{array}{l}\text { Keywords: } \\
\text { Pebula; Corruption } \\
\text { Prevention; Enforcement; } \\
\text { Buton Wisdom. } \\
\text { How to cite: } \\
\text { Munafi, L.O.A., Tahara, } \\
\text { T., Tenri, A., Malim, } \\
\text { D.D.L.O. (2020). Pebula: } \\
\text { Kearifan lokal masyarakat } \\
\text { buton dalam pencegahan } \\
\text { dan penindakan korupsi.. } \\
\text { ETNOSIA: Jurnal } \\
\text { Etnografi Indonesia. 5(1): } \\
67 \text { - } 78 .\end{array}$ & $\begin{array}{l}\text { Pebula is a Buton's terminology to refer to acts of corruption. The act } \\
\text { of pebula can be in the form of fraud or embezzlement of the state } \\
\text { budget, bribes, as well as taking advantage of deception by abusing } \\
\text { public office, authority, and power. In the social and state system in } \\
\text { Buton, there is a wisdom that reflects the spirit of eradicating pebula. } \\
\text { This spirit is manifest through several practices in the life of the } \\
\text { community and state that functionally reflect prevention and action } \\
\text { (law enforcement) of criminal acts pebula. This study was conducted } \\
\text { with a qualitative approach using data collection techniques through } \\
\text { the manuscript, library research, and in-depth interviews with } \\
\text { informants. This article describes how the prevention and enforcement } \\
\text { approach to "pebula" is practiced in the society and state life in Buton } \\
\text { as an effort to actualize a clean and accountable governance. }\end{array}$ \\
\hline $\begin{array}{l}\text { DOI: } \\
\text { 10.31947/etnosia.v5i1.8559 }\end{array}$ & \\
\hline
\end{tabular}

\section{Pendahuluan}

Korupsi merupakan tindakan penyalahgunaan kekuasaan yang menjadi persoalan sepanjang jaman di semua tradisi kebudayaan (Priyono, 2018:58). Korupsi senantiasa berkelindan dengan kekuasaan. Sebagai fenomena kejahatan, korupsi bertentangan dengan kaidah-kaidah kejujuran dan norma hukum yang tidak saja berdampak pada terancamnya stabilitas negara tetapi sekaligus menodai prinsip keadilan, kesejahteraan rakyat, serta nilai-nilai agama. Untuk mewujudkan pemerintahan yang bersih dari korupsi diperlukan mekanisme kontrol yang ketat terhadap pengelolaan kekuasaan 
sekaligus perlunya internalisasi nilai budaya anti korupsi dalam kehidupan bermasyarakat (Santoso dan Dewi Meyraswati, 2015:35).

Sebagai bentuk kejahatan luar biasa (ekstra ordinary craim) dalam sistem hukum moderen, korupsi bukanlah sesuatu yang asing dalam sistem pengetahuan masyarakat Buton. Hal ini ditunjukan melalui sejumlah praktek dalam kehidupan bermasyarakat dan bernegara di Buton yang secara fungsional merefleksikan upaya pemberantasan korupsi. Upaya pemberantasan korupsi, baik melalui praktek pencegahan maupun penindakan (penegakan hukum) merupakan salah satu aspek penting dalam kehidupan bermasyarakat dan bernegara di Buton yang sejauh ini belum memperoleh perhatian kalangan ilmuan.

Dalam pengetahuan umum, Buton seringkali dihubungkan dengan aspal, karena jenis mineral ini merupakan hasil tambang yang utama di Buton sejak jaman kolonial (Suryadi, 2007:287). Ternyata, Buton memiliki sejarah panjang lebih dari sekedar negeri penghasil aspal. Dahulu, Buton adalah kerajaan berdaulat di Nusantara yang turut mengonstribusi pembentukan ke-Indonesia-an. Selama eksis dari abad ke-14 hingga abad ke-20, Kerajaan Buton dipimpin enam orang raja (diperkirakan pada era praIslam), serta 37 orang sultan, ketika negeri itu bermetamorfosis menjadi kerajaan Islam (kesultanan) pada awal abad ke-16. Kesultanan Buton dihapuskan tahun 1960 setelah sultannya yang terakhir, La Ode Muhammad Falihi Qaimuddin, wafat beberapa bulan sebelumnya (Schoorl, 2003:136).

Pebula adalah terminologi Buton yang secara esensial sama pengertiannya dengan korupsi menurut bahasa Indonesia. Pebula adalah perbuatan memperkaya diri dengan menyalahgunakan jabatan, wewenang, dan kekuasaan publik. Perbuatan pebula dapat berupa penyelewengan atau penggelapan uang negara, suap, hingga menarik keuntungan dengan jalan menipu, dengan memanfaatkan kekuasaan, jabatan, atau wewenang sebagai pejabat publik (Zahari, 1977:71; Addin, dkk, 2011:3). Dalam konstitusi Buton yang disebut Undang-Undang Martabat Tujuh, pebula digolongkan sebagai perbuatan yang bertentangan dengan esensi nilai-nilai kemanusiaan dan ketuhanan, sebagai landasan pokok adat di Kesultanan Buton. Karena itu, pebula, sebagai tindakan kejahatan yang dampaknya disadari dapat menyebabkan kerusakan dalam sistem bermasyarakat dan bernegara, wajib dihindari setiap pejabat kesultanan (La Niampe, 2009:92). Pelanggaran atas larangan pebula dikenai sanksi tegas.

Kajian ini mencoba menggali sisi kearifan masyarakat Buton dalam upaya pemberantasan pebula (korupsi) melalui pendekatan antropologi hukum. Secara empirik, praktek hukum sangat dipengaruhi oleh budaya suatu masyarakat, baik dalam tatanan nilai maupun praktek hidup keseharian (Daliyo, 1992:139). Mengacu pada Hadikusuma (1986), praktek pemberantasan pebula, adalah salah satu refleksi dari produk budaya hukum masyarakat Buton.

\section{Metode}

Artikel ini merupakan hasil penelitian tentang praktek pemberantasan pebula, atau korupsi menurut bahasa Indonesia, dalam kearifan masyarakat Buton. Data penelitian bersumber dari sejumlah manuskrip lokal serta bahan-bahan tertulis lainnya yang mengandung muatan nilai budaya anti korupsi serta bentuk penegakan hukum atas praktek tersebut dalam kehidupan bernegara di Buton masa lalu. Untuk melengkapi 
kajian juga dilakukan wawancara mendalam dengan informan yang terdiri dari tokoh adat, tokoh budaya, akademisi, dan penggiat anti korupsi. Kajian juga dikuatkan dengan studi literatur terkait permasalahan korupsi di Indonesia pada umumnya. Data penelitian dianalisis secara deskriptif kualitatif melalui proses reduksi, penyajian dalam bentuk deskripsi dan penjelasan (penafsiran), serta penarikan kesimpulan.

\section{Hasil penelitian dan pembahasan}

\section{- Sosio-Politik Kesultanan Buton}

Kerajaan Buton didirikan oleh kelompok imigran yang berasal dari Semenanjung Malaka sekitar awal abad ke-14. Imigran ini dipimpin empat orang pemuka, yang dalam tradisi lokal disebut mia patamiana (Zahari, 1977:26). Raja pertamanya seorang perempuan, bernama Wa Kha Kha. Dalam mitologi Buton, ia disebut ratu keturunan dewa yang lahir melalui bambu. Wa Kha Kha menikah dengan Sibatara, seorang pangeran dari Majapahit. Dari pasangan inilah, generasi raja-raja Buton diturunkan. Di masa rajanya yang keenam, bernama Lakilaponto, Islam merambah wilayah Buton hingga negeri ini pun bermetamorfosis menjadi kerajaan Islam (kesultanan). Islamisator pertama di Buton adalah Syaikh Abdul Wahid Bin Sulaiman, mubaliq berkebangsaan Arab, yang datang dari Johor. Sebagai dampak diadaptasinya Islam, maka rajanya yang keenam dikukuhkan menjadi Sultan Buton I tahun 948 H (1541 M), bergelar Sultan Muhammad Qaimuddin, atau disebut juga Sultan Murhum.

Pola pemerintahan Kesultanan Buton dilandasi oleh tradisi lokal dan Islam. Struktur kekuasaan memperlihatkan berjalannya mekanisme pemerintahan yang tidak dapat dilepaskan dari sistem pelapisan sosial yang mengisinya. Lapisan tinggi dalam masyarakat ini disebut kaomu. Mereka dipandang sebagai kalangan mulia (Anceaux, 1987:67), atau kaum ningrat (Schoorl, 2003:213), atau golongan bangsawan tinggi (Rudyansjah, 2009, Tahara, 2014). Mereka berasal dari keturunan menurut garis bapak dari pasangan raja pertama. Sebagai penanda status, orang-orang kaomu menggunakan gelar, La Ode untuk laki-laki dan Wa Ode untuk perempuan, di depan nama mereka (Schoorl, 2003:213). Koamu terdiri atas tiga kelompok kerabat, yang disebut kamborumboru talupalena (tiga tiang penyanggah), terdiri atas: (i) kaomu tanayilandu, (ii) kaomu tapitapi, dan (iii) kaomu kembewaha. Sultan dipilih dari kalangan ini dan sejumlah jabatan tinggi lainnya dalam organisasi kesultanan juga dicadangkan untuk mereka.

Lapisan kedua disebut walaka. Lapisan bangsawan rendah ini berasal dari keturunan menurut garis bapak dari mia patamiana, founding fathers Kerajaan Buton. Lapisan sosial walaka juga terdiri atas tiga kelompok kerabat yakni: (i) walaka yi Bariya, (ii) walaka yi Kabumbu, dan (iii) walaka yi Melai (Tahara, 2014:93). Dari walaka inilah, siolimbona, semacam lembaga legislatif, dibentuk. Kecuali bertugas mengawasi jalannya pemerintahan, lembaga ini juga berfungsi memilih, melantik, bahkan memakzulkan sultan. Anggotanya terdiri atas sembilan bonto yang merupakan ahli dibidang adat, sekaligus berfungsi memeliharanya. Melalui kedudukan walaka dalam siolimbona, keseimbangan kekuasaan dengan kaomu dalam pemerintahan dapat terjaga, kaomu menjalankan fungsi eksekutif, dan walaka menjalankan fungsi legislatif.

Sebagai kelompok penguasa, kaomu dan walaka berdomisili di Wolio, wilayah pusat pemerintahan kesultanan. Keduanya dibedakan secara tajam dari papara, selaku lapisan 
ketiga dalam struktur masyarakat Buton. Mereka berdomisili di luar pusat kesultanan (Wolio), yang disebut kadie. Pada masing-masing kadie yang berjumlah 70 wilayah dibentuk perangkat pemerintahan lokal yang otonom, disebut sara kadie, yang dijabat para pemuka dari kadie bersangkutan. Masing-masing kadie berada di bawah pembinaan pejabat pusat kesultanan, disebut bobato (lakina) jika berasal dari kaomu, dan bonto jika berasal dari walaka.

Dalam sistem kekuasaan di Buton, jabatan sultan tidak diwariskan. Sultan dipilih melalui proses yang dijalankan siolimbona. Proses pengangkatan sultan dilakukan melalui mekanisme "pemilihan", dengan calon yang berasal dari tiga golongan kaomu (kamborumboru talupalena). Pembatasan kekuasaan sultan tampak pada kenyataan bahwa ia dapat dilengserkan, bahkan dapat dihukum mati (Schoorl, 2003:84).

Dengan gambaran di atas dipahami bahwa tata kelola negara di Buton ditandai sistem pembagian kekuasaan yang disangga golongan kaomu dan walaka. Arsitektur kekuasaan ditopang oleh sistem pemerintahan dan sistem nilai yang kuat, yang unsur-unsurnya meliputi: (i) sistem politik dalam negeri yang terdiri dari beberapa lapis kepemimpinan dan birokrasi yang tertata baik, serta di isi pula oleh para pejabat yang berasal dari kalangan terpilih, dan juga sistem politik yang menjadikan sultan dipilih melalui proses seleksi yang ketat oleh siolimbona, (ii) rakyat dan para pemimpinnya menganut nilainilai luhur yang sudah mengakar dari tradisi sosial yang baik, serta nilai-nilai agama yang mereka anut secara baik pula, (iii) terdapat sistem politik yang menganut sistem pembagian kekuasaan (power sharing) yang baik sehingga terdapat check and balances yang baik pula untuk menghindari kepemimpinan yang otoriter dan dictatorship, dan (iv) terbentuknya tatanan berupa konstitusi, di mana isi dari tatanan tersebut diadaptasi dari ajaran tasawuf (Anwar, 2018:11).

Kesultanan Buton dipimpin oleh sultan yang berasal dari kaomu, namun bukan dari satu keluarga saja. Tiap-tiap keluarga dalam tiga golongan kaomu (kamborumboru talupalena) mempersiapkan anggota keluarganya untuk diseleksi pada setiap momen pemilihan sultan. Melalui proses seleksi yang ketat dalam siolimbona, kemudian dipilih calon yang memiliki track record baik, serta visi yang jelas tentang bagaimana negara diarahkan di tengah dinamika lingkungan serta tuntutan dari rakyatnya. Grand strategy suatu negara menyangkut hal-hal utama tentang bagaimana mewujudkan core interest atau kepentingan nasional yang utama. Kesultanan Buton menetapkan bahwa kepentingan utamanya adalah survival atau keberlangsungan eksistensi negara (Anwar, 2018:13). Selain faktor ancaman eksternal (lihat, Zuhdi, 2018), jaminan keberlangsungan eksistensi negara dimaksud juga terefleksi pada upaya mewujudkan tata kelola pemerintahan yang bersih dari praktek pebula.

\section{- Pencegahan Pebula secara Yuridis Konstitusional}

Konstitusi Buton yang disebut Undang-Undang Martabat Tujuh disusun sebagai landasan untuk mengatur jalannya kekuasaan, sekaligus memberikan orientasi kepada penguasa untuk mewujudkan tujuan dan cita-cita bernegara. Disebut Martabat Tujuh karena konstitusi yang dirumuskan dan diundangkan Sultan Buton IV, Dayanu Ikhsanuddin tahun $1610 \mathrm{M}$ itu, mendapatkan pengaruh dari ajaran tasawuf Martabat Tujuh, paham wujudiyah dalam dunia tasawuf yang diadaptasi di Buton sejak awal abad 
ke-17 (Yunus, 1995:20). Naskah konstitusi ini terdiri atas 12 bab, meliputi: (1) mukadimah (pembukaan), (2) ketentuan tentang pejabat kesultanan, (3) struktur pemerintahan pusat kesultanan, (4) hirarki hukum (peraturan), (5) prosedur persidangan, (6) dewan agama, (7) institusi peradilan, (8) wilayah kekuasaan, (9) pertahanan keamanan, (10) keuangan, (11) hak-hak rakyat, dan (12) lambang kesultanan, bendera, dan bahasa (Addin, dkk , 2011).

Dalam mukadimah konstitusi Martabat Tujuh disebutkan empat jenis perbuatan yang bertentangan dengan adat, sekaligus dapat membinasakan tujuan dan cita-cita bernegara. Selain, (i) sabaragau, (ii) lempagi, dan (iii) pulu mosala te mingku mosala, jenis perbuatan dimaksud adalah pebula. Pebula adalah perbuatan memperkaya diri dengan menyalahgunakan jabatan, wewenang dan kekuasaan, yang bentuknya dapat berupa penyelewengan atau penggelapan uang negara, suap, pungutan liar, hingga menarik keuntungan dengan jalan menipu (Zahari, 1997:71; Addin, dkk, 2011:7). Batasan pengertian ini melingkupi tiga bias definisi dalam studi korupsi, yaitu: (a) bias hukum (korupsi sebagai pelanggaran hukum, (b) bias sentrisme-negara (korupsi sebagai penyelewengan kekuasaan/jabatan pemerintahan), dan (c) bias ekonomi (korupsi sebagai penyelewengan keuangan publik) (Priyono, 2018:57). Sebagai perbuatan yang disadari dapat merusak sendi-sendi kehidupan bermasyarakat dan bernegara, pebula wajib dihindari setiap pejabat kesultanan.

Sebagai kesultanan yang mengadopsi nilai-nilai tasawuf dalam konstitusinya, maka nilai-nilai kemanusiaan dan ketuhanan menjadi spirit kehidupan bernegara di Buton. Pejabat kesultanan memikul tanggung jawab mengarahkan bahtera negara pada pencapaian tujuan dan cita-citanya, yakni mewujudkan kesejahteraan rakyat sebagai manifestasi pengabdian kepada Tuhan. Tujuan dan cita-cita tersebut hanya akan dapat diwujudkan manakala pemerintahan terkelola secara bersih dan akuntabel. Ke arah itu, selain diperlukan mekanisme kontrol dalam pengelolaan kekuasaan sebagaimana terefleksi melalui power sharing system antara kekuasaan eksekutif yang ditopang golongan kaomu dan kekuasaan legislatif yang ditopang golongan walaka, juga mesti dibarengi integritas moral jajaran pejabat agar tidak terlibat praktek penyalahgunaan kekuasaan. Karena itulah, konstitusi Martabat Tujuh memberi orientasi tentang sifat-sifat yang wajib diteladankan pejabat kesultanan melalui pengamalan "empat amanat kerasulan" dan "tujuh sifat ketuhanan". Empat amanat kerasulan dimaksud meliputi: (a) sidik, artinya setiap pejabat kesultanan wajib berlaku benar dan jujur dalam pelaksanaan tugas-tugasnya, (b) tablig, artinya setiap pejabat kesultanan dituntut keselarasan antara ucapan dan tindakannya, (c) amanat, artinya setiap pejabat kesultanan adalah orang yang terpercaya, dan (d) fathona, artinya setiap pejabat kesultanan adalah orang yang perkataan atau ucapannya dapat memberikan kesejukan kepada masyarakat. Sedangkan, tujuh sifat ketuhanan dimaksud meliputi: (1) hiyaat yakni "hidup" (dhadhi), sebagai orientasi bahwa setiap pejabat kesultanan mesti memiliki kesiapan fisik dan mental untuk secara total dapat mewakafkan "hidupnya" bagi kepentingan publik. Dalam pemahaman ini, pejabat dituntut dapat "memberi kehidupan" kepada masyarakat, bukan sebaliknya, "mengambil hidup" masyarakat. Memberi kehidupan dalam pengertian ini termanifestasi melalui kemampuannya menangani dan menyelesaikan masalah-masalah publik. Sedangkan, "mengambil 
kehidupan" dalam pengertian dimaksud antara lain mencakup perbuatan pebula. Ketika pejabat terlibat pebula, maka sama halnya ia mengambil, bahkan merampas kehidupan publik. Perbuatan seperti ini bertentangan dengan salah satu prinsip dasar adat Buton, yinda-yindamo karo somanamo lipu, yakni kepentingan negeri harus diletakan di atas kepentingan pribadi dan golongan; (2) ilmu yakni pengetahuan (katau), sebagai orientasi bahwa setiap pejabat kesultanan wajib memiliki pengetahuan paripurna tentang tugas-tugas yang diembannya. Berbekal pengetahuan yang paripurna, pejabat diharapkan tidak terlibat tindakan penyalahgunaan kekuasaan, termasuk melakukan pebula; (3) kodrat yakni "kekuasaan" (kapooli), sebagai orientasi bahwa kekuasaan yang diamanatkan kepada pejabat publik mesti digunakan sebagai media untuk berperan aktif mewujudkan tujuan dan cita-cita bernegara dalam semangat pengabdian total kepada Tuhan; (4) iradat yakni "kehendak" (kapeelu), sebagai orientasi bagi pejabat untuk menyalurkan manfaat dari jabatan yang diamanahkan padanya guna sebesar-besarnya kemaslahatan publik; (5) sama'a yakni "mendengar" (porango), sebagai orientasi bagi pejabat untuk terbuka terhadap aspirasi, bahkan kritik publik yang ditujukan padanya; (6) basyar yakni "melihat" (pokamata), sebagai orientasi bagi pejabat yang visioner; dan (7) kalam yakni "ucapan" (oni), sebagai orientasi bagi pejabat dalam menyampaikan suatu pernyataan yang tidak bersifat provokatif bagi masyarakat. Melalui pengamalan "empat amanat kerasulan" dan "tujuh sifat ketuhanan" yang mesti diteladankan melalui perilaku pejabat kesultanan, maka praktek penyalahgunaaan kekuasaan, termasuk tindakan pebula, diharapkan dapat dihindari.

Praktek lain pencegahan pebula secara yuridis konstitusional dimonumentalkan melalui "sumpah" yang diucapkan dalam prosesi pelantikan sultan. Dalam tradisi Buton, sumpah dalam prosesi pelantikan sultan tidak diucapkan oleh sultan yang dilantik. Sebaliknya, sultan yang dilantik itulah yang disumpahi. Dalam prakteknya, ketika berlangsung prosesi pelantikan, maka bontona baluwu, salah seorang pejabat utama dalam siolimbona, mengucapkan sumpah kepada sultan yang dilantik, agar dalam menjalankan kekuasaan tidak terlibat perbuatan yang bertentangan dengan adat. Di antara jenis perbuatan dimaksud adalah nepotisme, kolusi, dan korupsi. Penggalan kalimat sumpah di bawah ini merefleksikan hal tersebut:

Urango laodhe, urango laodhe, urango laodhe:

bholi upomataakea ruambali,

bholi upoande-andeaakea,

bholi upebulaakea o tana siy laodhe.

artinya:

Dengar La Ode, dengar La Ode, dengar La Ode (seruan Bontona Baluwu kepada sultan yang dilantik):

jangan melakukan nepotisme, jangan melakukan kolusi,

jangan melakukan korupsi di atas bumi negeri ini La Ode.

Selanjutnya, untuk mengarahkan sultan agar istiqomah menjalankan tugas dan wewenangnya sebagaimana tuntunan adat, terefleksi melalui penggalan dari lanjutan kalimat sumpah seperti tersebut di bawah ini: 
Bholi ualaakea kanciana bhia yi tangamu,

Bholi ualaakea kaciana sala yi tangamu,

Bholi ualakea kanciana kampurui yi bhaamu.

artinya:

Jangan kau pertukarkan dengan bekas kain sarung di badanmu, Jangan kau pertukarkan dengan bekas kain celana di badanmu,

Jangan kau pertukarkan dengan bekas kain ikat kepalamu.

Penggalan kalimat sumpah di atas secara etis memberi orientasi yang tegas kepada sultan agar tidak melakukan perbuatan melanggar adat dengan "menukar wewenangnya", yang dalam ungkapan adat digunakan metafora "bekas kain yang pernah dikenakannya sekalipun", untuk tujuan memperkaya diri. Yang dimaksud menukar wewenang untuk tujuan memperkaya diri, sebagaimana makna esensial dari penggalan kalimat sumpah di atas, adalah menerima "suap", "gratifikasi", maupun jenis "transaksional" lainnya dengan menggunakan kekuatan jabatan dan wewenangnya sebagai pejabat publik.

Peringatan kepada sultan untuk menghindari segala bentuk perbuatan yang bertentangan dengan adat, yang juga dapat dimaknai sebagai instrumen yuridis konstitusional pencegahan pebula, termanifestasi melalui keberadaan "tali pintalan kain" (berwarnah merah) yang menggantung pada payung kemuliaannya. Tali pintalan kain tersebut, secara simbolik, menjadi pengingat bagi sultan, bahwa ketika terjerumus dalam perbuatan melanggar adat, termasuk melakukan pebula, ia akan menghadapi jeratan hukum.

Bentuk praktek lain yang juga dapat dimaknai sebagai instrumen yuridis konstitusional pencegahan pebula termanifestasi melalui ketentuan "larangan ke pasar bagi pejabat kesultanan". Makna etis yang terkandung dalam larangan ini adalah pejabat kesultanan dilarang berbisnis (Ali Mazi, 2019:9). Larangan ini dipahami, karena ketika pejabat publik terlibat urusan bisnis, yang dalam ungkapan adat digunakan "metafora pasar" akan berdampak pada konflik kepentingan (conflic of interest). Dalam keadaan demikian, praktek penyalahgunaan jabatan, dimungkinkan terjadi. Larangan ini sekaligus dimaksudkan agar pejabat kesultanan lebih fokus menjalankan tugas-tugas kenegaraan yang diamanatkan padanya.

\section{- Internalisasi nilai budaya pencegahan Pebula}

Setiap masyarakat mempunyai sistem nilai budaya yang mengatur pola pikir dan tatakelakuan warga masyarakat bersangkutan. Sistem nilai tersebut merupakan konsepsi abstrak yang hidup dalam alam pikiran masyarakat, karena itu mempengaruhi sikap dan pandangan warga masyarakat bersangkutan tentang pelbagai hal yang berhubungan dengan kehidupannya. Sebagai kesultanan yang mengadopsi nilai-nilai tasawuf sebagai spirit dalam kehidupan bermasyarakat dan bernegara, penghormatan terhadap nilai-nilai kemanusiaan, sebagai manifestasi pengabdian kepada Tuhan, begitu mengakar dalam pemahaman masyarakat Buton. Dalam sistem kekuasaan, refleksi pemahaman tersebut juga mencakup bagaimana mereka memaknai "jabatan". 


\section{P-ISSN: 2527-9319; E-ISSN: 2548-9747}

Dalam filosofi kepemimpinan Buton, jabatan adalah sodha (harafiah: "pikul"), yakni "sesuatu" yang dipikul. "Sesuatu" yang dimaksud dalam pengertian ini adalah "amanah". Karena itu, jabatan dimaknai sebagai amanah yang dipikul, bukan dipangku atau di duduki. Jabatan (sodha), yang berisi suatu amanah akan dipertanggungjawabkan, tidak hanya kepada publik tetapi juga kepada Tuhan. Pemahaman ini memberi orientasi kepada pejabat untuk menjadikan jabatan atau amanah yang dipikulnya sebagai media untuk mengabdi kepada Tuhan melalui pengabdian memajukan kemaslahatan publik. Karena itu, kesempatan menjadi pejabat semestinya tidak digunakan untuk mengejar kepentingan pribadi, termasuk memperkaya diri dengan cara pebula, melainkan pada hasrat untuk menyalurkan manfaat bagi publik sebagai manifestasi pengabdiannya kepada Tuhan. Itulah sebabnya, pejabat (pemimpin pada umumnya) dalam paham Buton, diidealkan dapat berperan sebagai polubha (pengayom dalam kehidupan publik), kaynawa (pembawah kesejahteraan dalam kehidupan publik), dan padhoma (teladan dalam kehidupan publik). Begitu penting dan strategisnya kedudukan pejabat publik, maka dalam filosofi kepemimpinan Buton ada ungkapan, bahwa "pejabat atau pemimpin akan tidur setelah rakyat tidur, dan mereka sudah harus bangun dari tidurnya sebelum rakyat bangun". Ungkapan ini merefleksikan tanggungjawab yang dipikul pejabat untuk senantiasa mengedepankan kepentingan publik sebagai manifestasi pengabdiannya kepada Tuhan. Karena itu, tindakan penyalahgunaan kekuasaan seperti pebula, yang berpotensi dilakukan pejabat publik, dipandang sebagai pengkhianatan terhadap sodha.

Esensi nilai-nilai kepemimpinan publik yang menempatkan jabatan sebagai media pengabdian kepada Tuhan, melalui pengabdian memajukan kemaslahatan publik, merupakan bagian dari sistem pengetahuan masyarakat Buton. Sistem pengetahuan tersebut menjadi salah satu muatan nilai pendidikan yang diinternalisasikan, tidak saja kepada seseorang yang akan menjadi pejabat, tetapi bahkan sejak dini pada anak-anak.

Dalam praktek di lingkungan keluarga kaomu dan walaka, dua golongan penyangga kekuasaan di Buton, anak-anak pejabat sejak dini telah disertakan menjadi bhelobhamba (harafiah: hiasan balairung), dengan melibatkan mereka secara langsung dalam aktivitas di lingkungan kehidupan istana. Melalui praktek seperti ini, anak-anak sejak dini dapat belajar banyak hal, tentang tata-krama, kedisiplinan, kejujuran, tanggungjawab, kepemimpinan, dan sebagainya. Melalui pola pembinaan demikian, kelak ketika dewasa dan menjadi bagian penting dalam masyarakat (menjadi pejabat kesultanan), mereka diharapkan dapat bersikap dan berperilaku sebagaimana tuntunan adat. Menjauhi segala bentuk perbuatan tercela, termasuk pebula, adalah bagian dari tuntunan adat itu sendiri.

Internalisasi nilai budaya yang secara fungsional turut mempengaruhi perkembangan kepribadian anak-anak juga terefleksi melalui muatan nilai pendidikan dalam zawiyah, yakni institusi pendidikan serupa pesantren dalam lingkungan keraton. Disain kurikulum pendidikan zawiyah tidak hanya berorientasi pada pengetahuan agama tetapi juga pendidikan akhlak dan budi pekerti. Melalui muatan nilai pendidikan yang diperoleh dalam zawiyah, generasi muda disiapkan menjadi calon-calon pemimpin kesultanan di masa depan. Sejumlah sultan di Buton, seperti almukarram La Ode Muhammad Aydrus Qaimuddin Bin Badaruddin al Butuny (Sultan Buton ke-29, 
memerintah: 1824-1821), merupakan salah seorang sultan yang mengukir prestasi gemilang dalam perkembangan peradaban Islam di Buton (Yunus, 1995:75). Ketika alumnus Zawiyah Galampa Bhatu ini menjabat sultan, pejabat kesultanan yang terlibat pebula dijatuhi hukuman tatalima (potong tangan) disamping dimakzulkan dari jabatannya.

Muatan nilai pendidikan lainnya yang diinternalisasikan sejak dini kepada anak-anak adalah penanaman nilai budaya kaea (budaya malu). Praktek seperti ini hingga sekarang masih terefleksi melalui sejumlah ungkapan yang disampaikan orang tua kepada anak-anaknya; maeakea karomu (jaga kehormatanmu), maeakea mancuanamu (jaga kehormatan orang tuamu), maeakea wititinaimu (jaga kehormatan keluargamu), maeakea manga opuamu (jaga kehormatan leluhurmu). Muatan nilai pendidikan seperti ini memberi orientasi kepada anak-anak untuk senantiasa menjaga sikap dan perilaku sebagaimana tuntunan adat. Karena, ketika seseorang terlibat perbuatan yang bertentangan dengan adat, termasuk pebula, maka perbuatan tersebut berakibat pada rusaknya kehormatan, tidak saja kehormatan pribadi, tetapi juga kehormatan orang tua, keluarga besar, bahkan leluhurnya; sebuah prinsip yang amat dijunjung dalam kehidupan keluarga. Orang Buton akan merasa kehilangan harga diri ketika disebut, apalagi dihardik dengan kata-kata, yinda koadhati (tidak beradat) atau yinda matau adhati (tidak tau adat). Pembentukan karakter anak-anak sejak dini melalui muatan nilai pendidikan seperti ini secara fungsional menyentuh kondisi mentalitas, moralitas, dan alam pikiran mereka. Kelak, ketika dewasa dan menjadi pejabat kesultanan, mereka diharapkan terhindar dari perbuatan tercela, termasuk pebula. Hal ini dipahami karena pendidikan merupakan strategi kebudayaan dalam rangka membangun kualitas sumberdaya manusia yang memiliki integritas sebagai pribadi maupun integritas sebagai warga negara (Santoso dan Dewi Meyraswati, 2015:41).

Internalisasi nilai budaya yang sekaligus dapat dimaknai sebagai gerakan moral pencegahan pebula juga terefleksi melalui penyebarluasan bahan bacaan kepada masyarakat berupa naskah-naskah kesusastraan yang disebut kabanti (pusi-syair, nyanian, sajak) (Anceaus, 1987). Dalam Kabanti Kamba Mpu tertulis untaian syair:
Mincuanapo yi sarongi rangkaea nesabutuna abhari arataana
Tabeanamo yisarongi rangkaea hengga hakumana apeka dhawuakamo
Mincuanapo yisarongi misikini nesabutuna yinda koarata
tabeanamo yisarongi misikini apeelumo arasi mokohakuna
artinya:
Belumlah disebut kaya jika baru memiliki harta yang berlimpah
Yang disebut kaya ketika haknya sekalipun (harta benda) diberikan
untuk kemaslahatan orang lain
Belumlah disebut miskin jika hanya tidak memiliki harta
Yang disebut miskin ketika hak orang lain pun diambilnya

Selain melalui kabanti, ada juga sejumlah ungkapan sehari-hari yang memiliki korelasi dengan upaya pencegahan pebula seperti tersebut berikut: 


\author{
Abharimpu giu yi binasaaka \\ Salasaangu pande ala mokohakuna \\ artinya: \\ Banyak sekali perkara yang membinasakan \\ Satu di antaranya adalah suka mengambil hak orang lain
}

Pesan-pesan moral sebagaimana tertuang dalam kabanti maupun ungkapan seharihari masyarakat tersebut mengandung nilai-nilai pendidikan karakter yang beririsan dengan upaya pencegahan pebula. Nilai-nilai tersebut menjadi orientasi dalam upaya mewujudkan aparatur kesultanan maupun masyarakat pada umumnya yang bersih dari perilaku pebula.

\title{
- Penegakan Hukum atas Tindak Pidana Pebula
}

Pebula adalah tindakan kejahatan yang tidak hanya bertentangan dengan moral kejujuran tetapi juga norma-norma hukum bernegara. Dalam konstitusi Martabat Tujuh, pebula digolongkan sebagai perbuatan yang bertentangan dengan landasan pokok adat, sekaligus merusak tujuan dan cita-cita bernegara. Karena itu, dalam sistem hukum di Buton, pebula digolongkan sebagai salah satu jenis tindak pidana. Penyelesaian terhadap kasus-kasus tindak pidana di Buton dilakukan melalui penegakan hukum adat. Secara materil, hukum adat Buton umumnya diadapasi dari materi hukum Islam. Testimoni Hamka (1983:175) seperti tersebut di bawah ini merefleksikan hal tersebut.

Di dalam negeri Kerajaan Buton telah dijadikan hukum adat merajam orang yang kedapatan berzina dengan disaksikan oleh saksi menurut ketentuan Al-Qur'an, dan telah pernah dipotong tangan orang yang mencuri. Disamping istana Raja Buton masih didapat batu hampar tempat orang menjalani hukum rajam dan potong tangan itu. Hukuman yang dijatuhkan atas tindak pidana pebula bermacam-macam, sesuai tingkat kesalahan yang dilakukan pelaku, mulai dari hukuman ringan hingga hukuman yang tergolong berat. Asalaiki tobha (kesalahan akibat pengelolaan harta perbendaharaan negara) menjadi semacam penghalusan semantik untuk menunjuk oknum pejabat yang terlibat tindak pidana pebula. Jenis-jenis penindakan hukum atas perbuatan pebula meliputi: (a) pasabu, yakni jenis penindakan hukum berupa pemecatan (pemakzulan) oknum pejabat dari pemerintahan. Selain pada kasus pebula, pasabu juga diberlakukan untuk jenis tindak pidana lainnya yang dilakukan oknum pejabat kesultanan; (b) tatalima, yakni jenis penindakan hukum berupa hukuman potong tangan kepada oknum pejabat. Jenis penindakan hukum ini juga diberlakukan terhadap pencuri; dan (c) gogoli, yakni jenis penindakan hukum berupa hukuman gantung hingga mati.

Penegakan hukum atas tindak pidana pebula maupun jenis tindak pidana lainnya diletakan pada asas bhone montete yinda posala-sala, artinya "tidak ada perbedaan bagi siapa pun dihadapan hukum". Dalam prinsip supremasi hukum di Buton, para pejabat kesultanan, termasuk sultan sekali pun tidak memperoleh hak imunitas (kekebalan) hukum dari negara. Dalam sejarah bahkan tercatat seorang sultan serta sejumlah petinggi kesultanan yang mengakhiri jabatannya di tiang gantungan, dikenai hukuman gogoli. 
Dalam konstitusi Buton, tidak ada ketentuan mengenai pembatasan masa jabatan sultan maupun jajaran birokrat kesultanan. Makanya, ada sejumlah sultan dan pejabat tinggi lainnya yang menjabat begitu lama, namun ada juga yang menjabat begitu singkat. Selain karena faktor meninggal dunia (berhalangan tetap) atau mengundurkan diri, masa jabatan seorang pejabat berakhir karena dimakzulkan. Pemakzulan erat kaitannya dengan "kesalahan" yang dilakukan dalam mengemban tugas-tugas pemerintahan, termasuk karena terlibat tindak pidana pebula. Inilah refleksi penegakan hukum yang tanpa pandang bulu dalam praktek bernegara di Buton. Praktek ini disamping berdampak pada terpeliharanya marwah (wibawa) hukum sekaligus menjadi jaminan bagi terwujudnya rasa keadilan di masyarakat.

\section{Kesimpulan}

Masyarakat Buton mememiliki kearifan dalam pemberantasan korupsi. Kearifan itu terefleksi, baik melalui rumusan norma dalam konstitusi kenegaraan mereka maupun melalui praktek internalisasi nilai budaya anti korupsi dalam kehidupan bermasyarakat. Praktek pemberantasan korupsi sebagai bagian dari produk budaya hukum masyarakat Buton merupakan refleksi sebuah kearifan guna mewujudkan tatanan hidup bernegara dan bermasyarakat yang bersih dan bebas dari korupsi.

Kearifan masyarakat Buton dalam pemberantasan korupsi juga merefleksikan pentingnya internalisasi nilai budaya sebagai instrumen pencegahan tindak pidana korupsi. Melalui pendekatan tersebut, penyelenggara negara maupun masyarakat pada umumnya, diharapkan tidak melanggar kaidah-kaidah sosial kemasyarakatan maupun kenegaraan, karena nilai dijadikan standar perilaku yang baik. Berpijak dari realitas kearifan masyarakat Buton dalam pemberantasan korupsi, artikel ini merekomendasikan perlunya pengkajian secara intensif nilai-nilai kearifan lokal masyarakat kita yang memiliki muatan nilai anti korupsi. Sebagai produk kebudayaan positif, nilai-nilai kearifan lokal tersebut dapat berfungsi sebagai instrumen kultural dalam upaya penanggulangan dan pemberantasan korupsi di Indonesia.

\section{Referensi}

Anceaux, J.C. (1987). Wolio Dictionary (Wolio - English - Indonesian). Foris Publication Holland.

Addin, Asnur, Sadidi, Kartono, Rahmat., Sarfan K.A. (2011). Israrul Umrai Fiy Adatil Wuzurai; Undang-Undang Martabat Tujuh dan Sifat Dua Puluh Kesultanan Buthuuni. Baubau: Yayasan Fajar Al Buthuuni.

Anwar, S. (2018). Sejarah Buton: Labu Rope Labu Wana, dan Pelajaran yang dapat Ditarik dari Nilai-Nilai Tersebut; "Makalah", disampaikan pada Seminar Budaya Forum Anak Kota Baubau". Baubau, 22 Nopember 2018.

Ali, M. (2019). Revitalisasi dan Reaktualisasi Nilai Budaya sebagai Instrumen Pencegahan Tindak Pidana Korupsi. "Makalah", disampaikan pada Seminar Forum OSIS Remaja Milenial Anti Korupsi. Baubau, 27 Juli 2019.

Daliyo, J.B. (1992). Pengantar Ilmu Hukum; Buku Panduan Mahasiswa. Jakarta: Gramedia. Hadikusuma, H. (1986). Antropologi Hukum Indonesia. Bandung: Alumni.

Hamka (1983). Tafsir Al Azhar Juz 1 dan 2. Jakarta: Pustaka Panjimas.

Niampe, L. (2009). Undang-Undang Buton Versi Muhammad Idrus Qaimuddin. Kendari: FKIP Unhalu. 
Priyono, B.H. (2018). Korupsi; Melacak Arti, Menyimak Implikasi. Jakarta: P.T. Gramedia Pustaka Utama.

Rudyansyah, T. (2009). Sejarah, Kekuasaan, dan Tindakan; Sebuah Kajian tentang Lanskap Budaya. Jakarta: Rajawali Pers.

Santoso, L., Meyraswati, D. (2015). Model Strategi Kebudayaan dalam Pemberantasan Korupsi di Indonesia. Jurnal Review Politik, Vol. 05 Nomor 01, Juni 2015, hal.2245.

Suryadi (2007). Surat-Surat Sultan Buton, Dayyan Asraruddin dan Kaimuddin I, Koleksi Universiteitsbibliotheek Leiden, Belanda. Jurnal Humaniora Vol.19, Nomor 3, Oktober 2007, hal.28-301.

Schoorl, P. (2003). Masyarakat, Sejarah, dan Budaya Buton. Jakarta: Penerbit Djambatan dan KITLV-Jakarta.

Tahara, T. (2014). Melawan Stereotipe; Etnografi, Reproduksi Identitas, dan Dinamika Masyarakat Katobengke Buton yang Terabaikan. Jakarta: Kepustakaan Populer Gramedia.

Yunus, A.R. (1995). Posisi Tasawuf Dalam Sistem Kekuasaan di Kesultanan Buton Pada Abad ke-19, Seri INIS; Jilid 24. Jakarta: Indonesian-Netherlands Cooperation in Islamic Studies.

Zahari, A.M. (1977). Sejarah dan Adat fiy Darul Butuni. Jakarta: Depdikbud.

Zuhdi, S. (2018). Sejarah Buton yang Terabaikan; Labu Rope Labu Wana (Edisi Revisi). Jakarta: Wedatama Widya Sastra. 